Biophysik 3, 123-130 (1966)

\title{
Characteristics of Three Nuclear Emulsions for Autoradiography at the Electron Microseope ${ }^{\star}$
}

\author{
D. F. HÜLSER and M. F. RAJEWSGY
}

Max-Planck-Institut für Biophysik in Frankfurt am Main (Direktor: Prof. Dr. B. RAJEwsky)

Received November 24, 1965

The demonstration of radionuclides, especially tritium, by microautoradiography of ultra-thin sections using the electron microscope may only be preferable to the use of the light microscope if photographic emulsions are available which, due to their grain size and sensitivity, guarantee a satisfactory resolution.
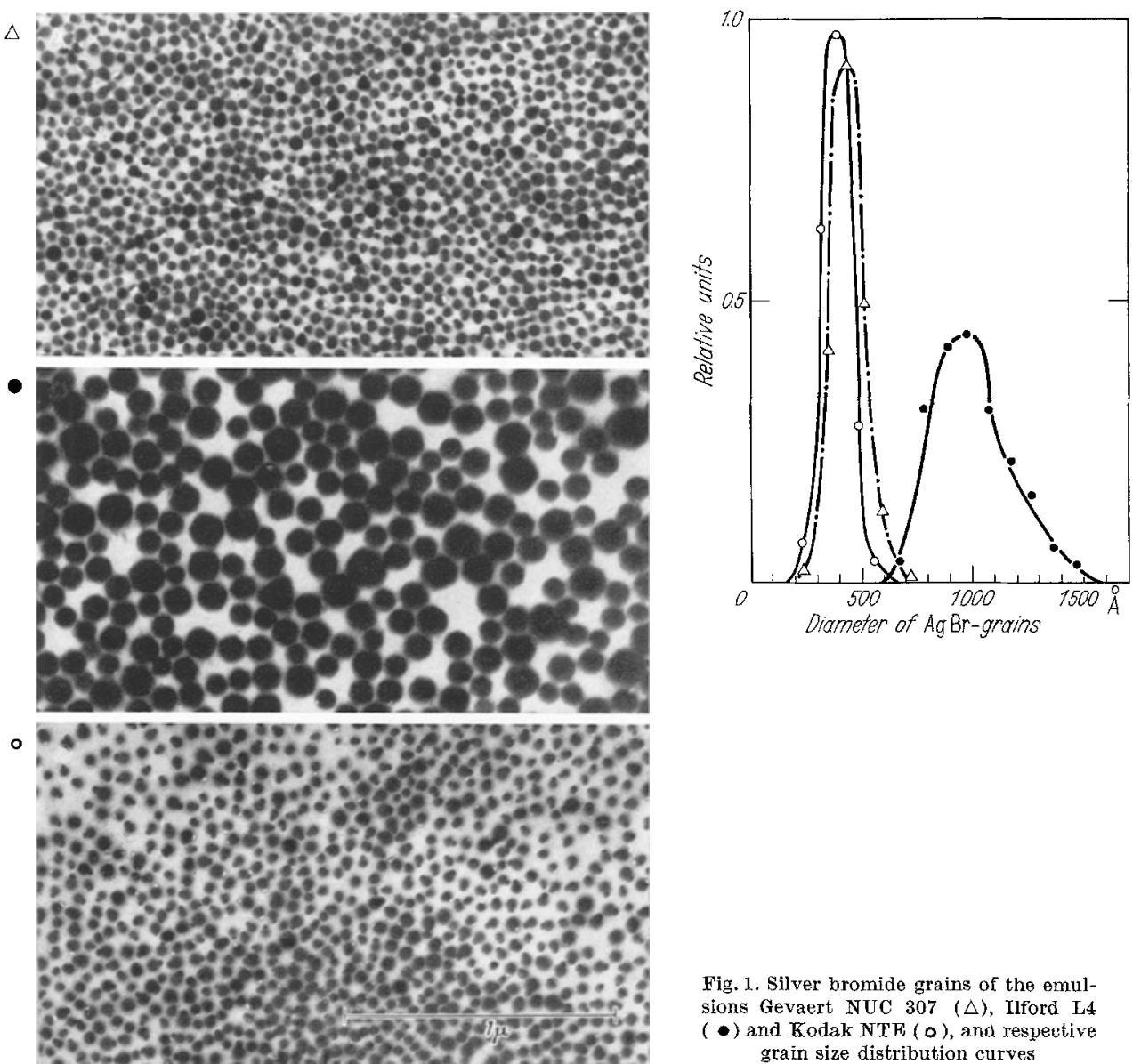

* Parts of the paper have been presented at the XI. International Congress of Radio$\log y$, Rome, September 1965.

Fig. 1. Silver bromide grains of the emulsions Gevaert NUC $307(\triangle)$, Ilford L4 (•) and Kodak NTE (o), and respertive grain size distribution curves 
Various techniques for different types of emulsions have been described by a number of authors $[3,5,6,7,8,12,13]$. Theoretical considerations of resolution and sensitivity have been published $[1,2,10,11]$, but most of these investigations were made on biological material which makes quantitative measurements difficult.

Three commercial emulsions, Gevaert NUC 307, Ilford L4 and Kodak NTE have therefore been investigated to assess their qualities for electron microscope microautoradiography, using physical methods for the determination of sensitivity. They were chosen on account of their low grain size. Following a technique described by CARO [3], the emulsions were applied to the formvar and carbon coated electron microscope platinum grids with a coppər wire loop.

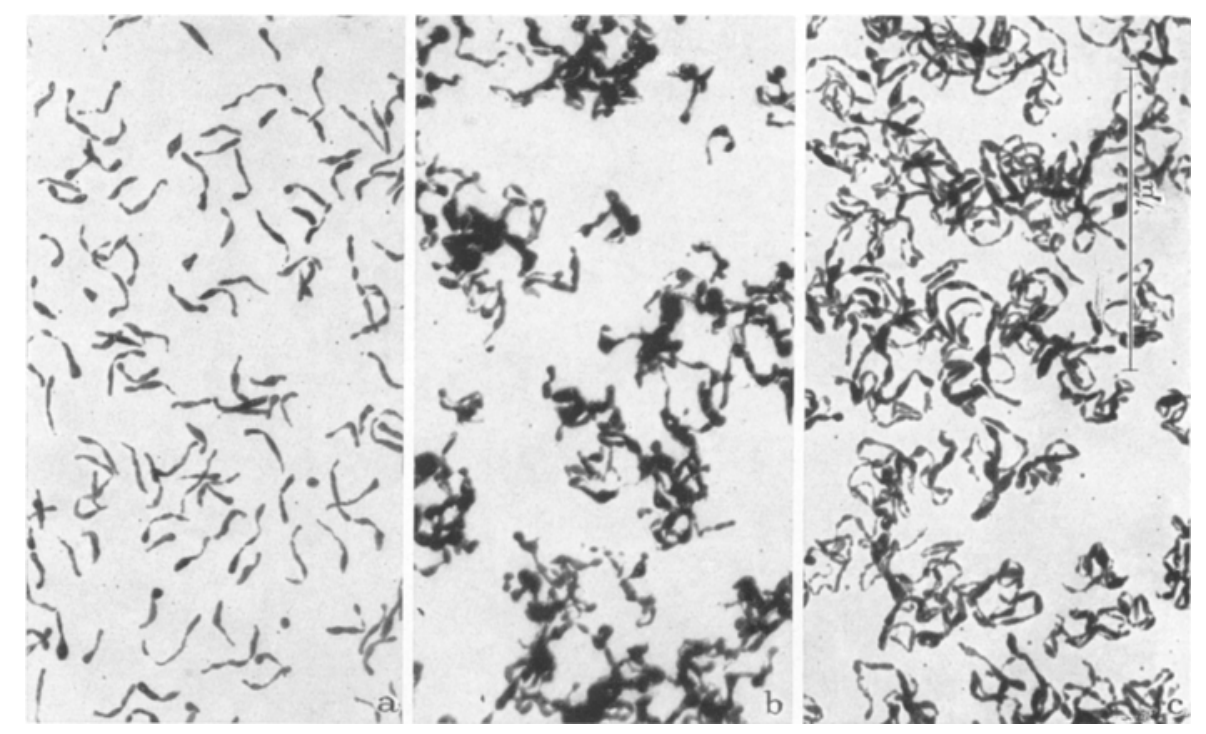

Fig. 2 a-c. Ilford L4 emulsion. Irradiation with $5.7 \mathrm{keV}$ electrons in the electron microscope. Development for 1 min in Microdol X (a), Kodak D19 (b), or Promicrol (c); 10 sec in acetic acid; fixation time 5 min in Kodak AM 33 Rapid Fixer

Fig. 1 shows the grain size distributions measured for the emulsions Gevaert NUC $307(0.04 \mu)$, Ilford L4 $(0.11 \mu)$ and Kodak NTE $(0.04 \mu)$. The grain size distribution curves of all three emulsions show half-width values of about $20 \%$ of the mean. Whereas the Ilford and Kodak emulsions were found to have the grain size stated by the manufactures, the value found for the Gevaert emulsion was about $40 \%$ lower than that stated. There may be variations of grain size between different batches of this emulsion and it is therefore advisable to check the grain size before use.

A developer suitable for microautoradiography should produce typically shaped silver filaments which are also as small as possible. Fig. 2 demonstrates for the emulsion Ilford L4 and a developing time of 1 min different types of silver filaments produced by three different developers. Physical development, as used by CARO [3] and other authors was not found to be suitable because of the likelihood of artefacts, a particularly serious problem in electron microscopy. Microdol 


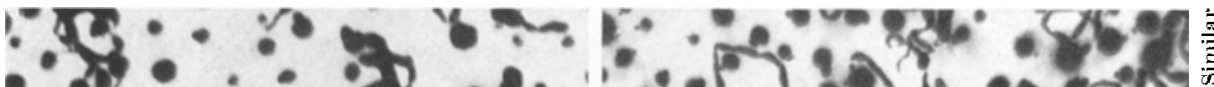

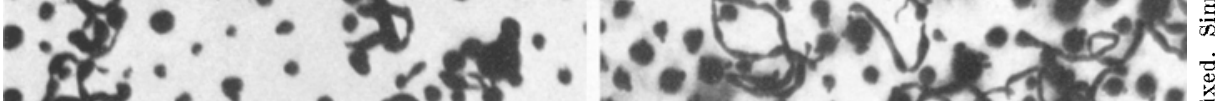

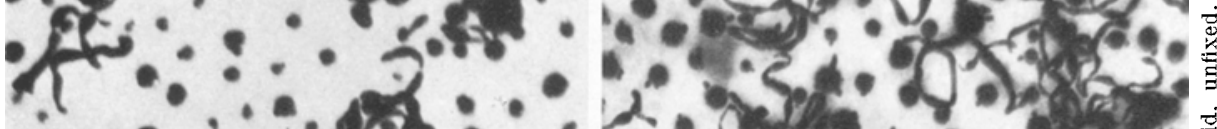
$\because \therefore \therefore 4: \because 2 \cdot 04010$ $\because \because \therefore 0^{2}$ a $\because 0^{\circ}: 08 \%$ $\because \because 9$ - 2.

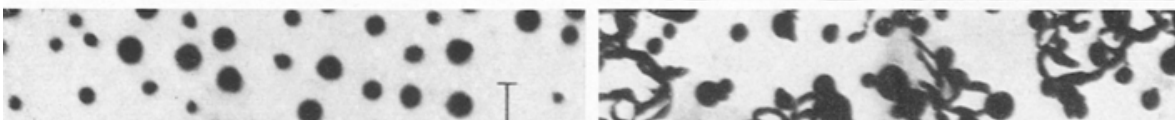
$\because \because \because$ O

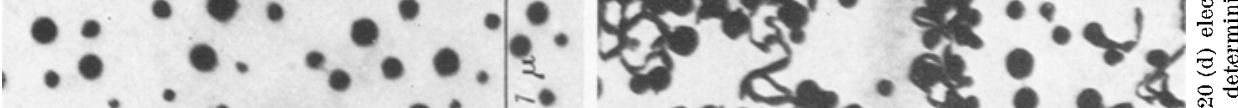
$\because \therefore \because \because \because 0^{\circ}$

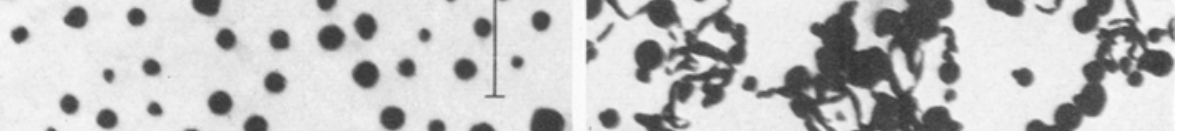
$\therefore \because \because \because \because \because:$ a

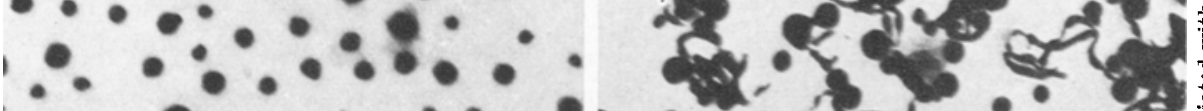
$\therefore \therefore \because \because \because \therefore$ \%

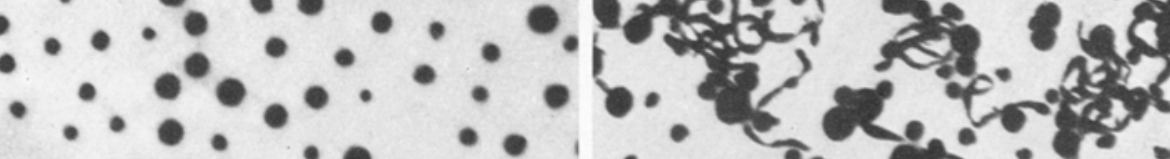

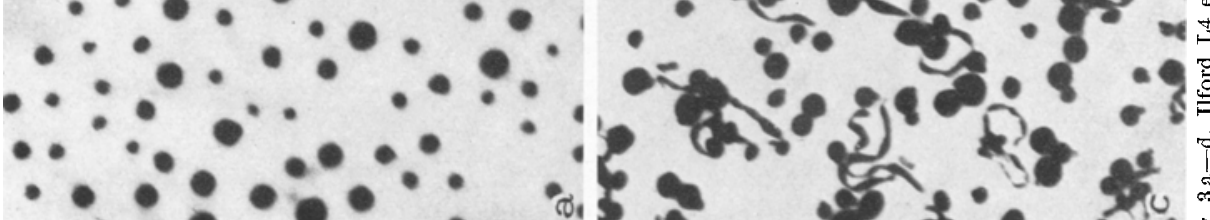
$\therefore \because \cdots$. 
X fine grain developer produced rather small silver filaments of typical shape in all three emulsions, the fine end of a filament coinciding with the locus of the original latent image in the $\mathrm{AgBr}$ grain. This developer was chosen for all subsequent experiments.

In order to test the sensitivity of the three emulsions in question, monolayer preparations have been irradiated in the electron microscope and measurements of electron intensity as electrons per $\mathrm{AgBr}$ grain have been made. The energy of the electron beam was maintained at $5.7 \mathrm{keV}$, corresponding to the mean $\beta$-energy of tritium, the radionuclide most frequently used in biological tracer studies. After irradiation in the electron microscope the specimens were developed in

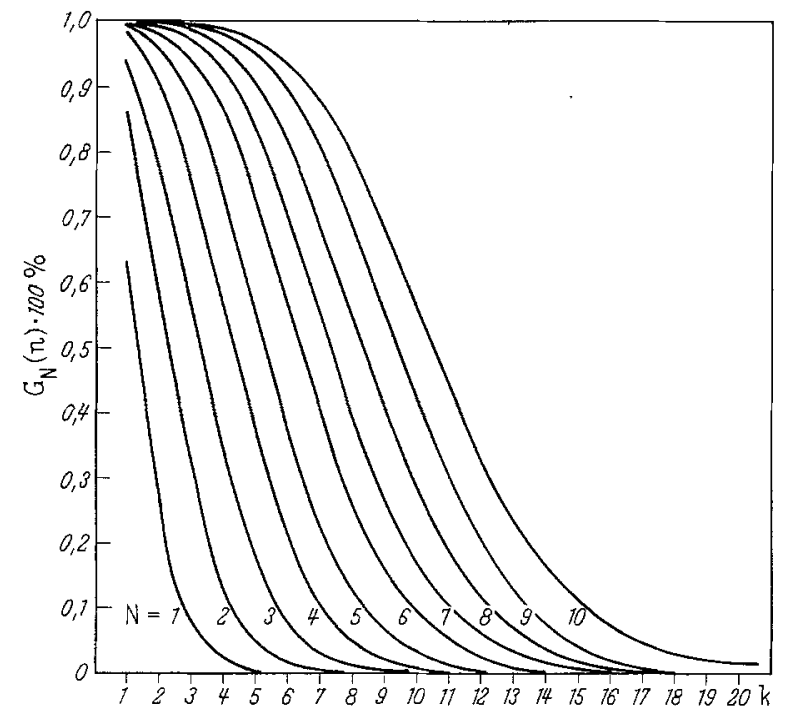

Fig. 4. Poisson distribution curves for the determination of the number of electrons necessary for the formation of one latent image.

$$
\begin{aligned}
& G_{N}(n)=1-e^{-N} \sum_{n=0}^{k-1} \frac{N^{n}}{n !} \\
& N \text { Number of electrons to which one AgBr grain was exposed } \\
& k \text { Number of electrons hitting one AgBr grain }
\end{aligned}
$$

Microdol $\mathrm{X}$ but left unfixed. This procedure permits the determination of the percentage $\mathrm{G}_{N}(n)$ of developed $\mathrm{AgBr}$ grains. Fig. 3 shows the result of a typical experiment with Ilford L4 emulsion and exposures to $0,1,2$, and 20 electrons per $\mathrm{AgBr}$ grain. Due to the short developing time of 1 min not all latent images grow out completely as it takes longer to develop the internal latent images than those on the surface of the grain. The points, however, where silver filaments are just starting to grow out from the grains are clearly distinguishable.

If we assume that electrons hit AgBr grains according to a Poisson distribution, we can calculate the number of grains which are hit by $k$ or more electrons when the mean exposure is $N$ electrons per grain. In Fig. 4 the percentage of developed $\mathrm{AgBr}$ grains is given on the ordinate, the number of electrons necessary for the formation of a latent image can be read from the abscissa.

Our experiments show that for the formation of one silver filament, one $\mathrm{AgBr}$ 
grain of the Ilford L4 emulsion must be hit on the average by $1-1.4$ electrons. The corresponding figures for the Gevaert NUC 307 and Kodak NTE emulsions are $2-3$ electrons and $4-5$ electrons respectively. The energy loss in silver bromide can be found from a formula by FeLdmann [4] and data published by Nelass [9] (see also Pelc [10]).

From the energy loss in silver bromide for $5.7 \mathrm{keV}$ electrons it can be estimated that the Ilford L4 and Gevaert NUC 307 emulsions absorb about $800 \mathrm{eV}$ for the formation of one latent image as compared to about $1300 \mathrm{eV}$ for the Kodak NTE emulsion.

In sections of biological material we are often dealing with plane sources of radioactivity. In this case, the differences in sensitivity between the emulsions are not large enough to be important. What may be more critical, particularly where the localisation of label in specific cell components is being studied, is the degree of resolution.

The resolution may be visualized as a sphere with the diameter of the $\mathrm{AgBr}$ grain as its radius, the center of the sphere being the latent image. For Microdol $\mathrm{X}$ developed grains the thin end of the filament corresponds to the latent image and hence to the center of the sphere. If, as in the case of Ilford L4 emulsion, only one electron is required for the formation of a latent image in one grain, it will undoubtedly have come from this sphere. For emulsions, however, which require several electrons for the formation of a latent image, the probability of the formation of a latent image must be taken into account. This is demonstrated in Fig. 5. The probability $P_{s}$ for latent image formation is a function of the number of electrons $i$, necessary for the production of one latent image, and of the probability for one $\mathrm{AgBr}$ grain to be hit by one electron.

$$
P_{s}=\left(\frac{r^{2}}{4 x^{2}}\right)^{i} \text {. }
$$

Normally one would assume that resolution goes up with decreasing grain size. As, however, the degree of resolution is proportional to the probability of latent image formation $P_{s}$ the advantage of emulsions with smaller grains is lost because the smaller the grains are the greater will be the number of electrons $i$ required for latent image formation. Regarding point sources this means that with emulsions requiring several electrons for latent im-

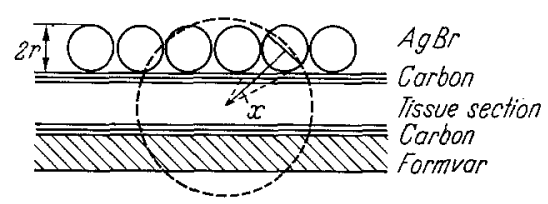

Fig. 5. The probability of latent image formation as a problem of resolution $r$ Radius of $\mathrm{AgBr}$ grain

$x$ Distance source - center of $\mathrm{AgBr}$ grain

Circle area: $F_{1}=\pi r^{2}$

Sphere surface: $F_{2}=4 \pi x^{2}$

Probability for one hit: $P_{t}=F_{1} / F_{2}=r^{2} / 4 x^{2}$

Probability for latent image formation: $P_{s}=\left(\frac{r^{2}}{4 x^{2}}\right)^{i}$

$i$ Number of electrons necessary for the formation of one latent image age formation very little labelling will be

obtained. In the case of line sources, as for instance membranes, the "electron collecting area" becomes so extended that the advantages of low grain size are eliminated, as was mentioned above. Hence, giving a similar resolution as the Gevaert NUC 307 emulsion, the Ilford L4 emulsion is preferred, because with a considerably shorter autoradiographic exposure time, results are of comparable quality.

In Fig. 6 the degree of resolution which can be obtained using Ilford L4 emulsion and Microdol $\mathrm{X}$ developer is demonstrated in a microautoradiogram of 
a cell from the transplantable 'Marshall' rat carcinoma. ${ }^{3} H$-thymidine has been incorporated into the DNA of this cell 'in vitro'. The resolution is shown by circles around several silver filaments.

It may be worth mentioning that another approach to produce suitable photo-

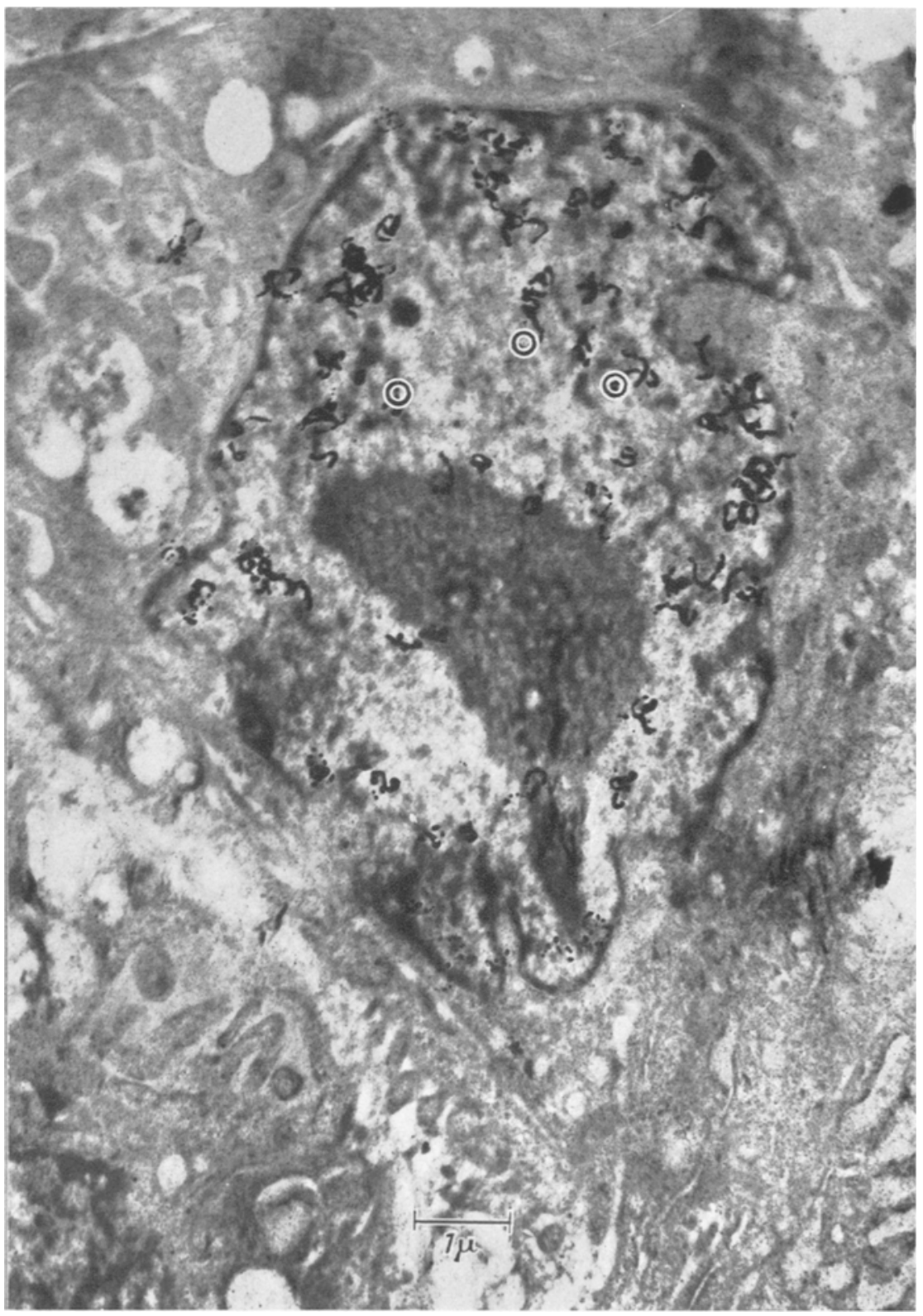

Fig. 6. Microautoradiogram of a section of the transplantable 'Marshall' rat carcinoma. 'In vitro' incubation with ${ }^{3} H$-thymidine $(20 \mu \mathrm{c} / \mathrm{ml})$ for $90 \mathrm{~min}$. Exposure time 15 days. Tlford L4 emulsion, developed for 2 min in Microdol $\mathrm{X}$, stopped in acetic acid, and fixed in Kodak AM 33 Rapid Fixer for 5 min. 
sensitive silver bromide with very small grain size has been vacuum evaporation of metallic silver and subsequent exposure to bromium vapour, a technique which has in principle been described by SILK et al. [13]. However, our results with this method indicate that although very small crystals of $\mathrm{AgBr}$ are indeed obtainable, the sensitivity of the grains is extremely low by comparison with commercially available autoradiographic emulsions in gel form.

The authors express their gratitude to Professor Dr. B. RAJEwsky for his support of this investigation. Thanks are also due to Dr. W. LIPPERT for valuable discussions, and to Miss W. Frtese and Miss S. Unger for technical assistance.

\section{Summary}

On account of their low grain size three commercial emulsions, Gevaert NUC 307, Ilford L4 and Kodak NTE have been investigated to assess their qualities for electron microscope microautoradiography. Grain size distribution curves were determined and a developer suitable for microautoradiography was selected after having tested different types of developers.

In order to investigate the sensitivities of the three emulsions, monolayer preparations were irradiated in the electron microscope, using an energy of $5.7 \mathrm{keV}$ corresponding to the mean $\beta$-energy of tritium. After exposure the specimens were developed but left unfixed. The sensitivity may then be determined using the percentage of developed grains. For the formation of one latent image the Ilford L4 emulsion must be hit on the average by $1-1.4$ electrons per $\mathrm{AgBr}$ grain; the corresponding figures for Gevaert NUC 307 and Kodak NTE are 2-3 and 4-5 respectively.

The problem of resolution of point and plane sources of radioactivity is discussed.

Future advances in microautoradiography will depend on the development of emulsions with lower grain sizes, but such improvement must not be at the expense of sensitivity.

\section{Zusammenfassung}

Drei handelsübliche Kernspuremulsionen, Gevaert NUC 307, Ilford L4 und Kodak NTE, wurden wegen ihrer geringen Korngrößè auf ihre Eignung zur elektronenmikroskopischen Autoradiographie untersucht. Korngrößenverteilungskurven wurden aufgenommen und ein geeigneter Entwickler ausgesucht.

Zur Bestimmung der Empfindlichkeit dieser drei Emulsionen wurden Einkornschichten im Elektronenmikroskop mit Elektronen einer Energie von $5,7 \mathrm{keV}$, der mittleren $\beta$-Energie des Tritiums, bestrahlt. Anschließend wurden die Emulsionen entwickelt, aber nicht fixiert. Mit dem Anteil der entwickelten AgBrKörner kann dann über Trefferkurven die Empfindlichkeit der Emulsionen bestimmt werden.

Man benötigt zur Bildung eines latenten Bildkeimes für die Ilford L4-Emulsion 1-1,4 Elektronen pro AgBr-Korn, für die Gevaert NUC 307-Emulsion 2-3 und für die Kodak NTE-Emulsion 4-5 Elektronen pro AgBr-Korn.

Folgerungen für das Auflösevermögen bei radioaktiven Punkt- und Flächenquellen werden diskutiert.

Fortschritte in der Mikroautoradiographie werden von der Entwicklung feinkörniger Emulsionen abhängen, deren Empfindlichkeit bei etwa einem Elektron pro AgBr-Korn liegen sollte. 


\section{References}

[1] Bachmann, L., and M. M. Satpeter: Autoradiography with the electron microscope. A quantitative evaluation. Lab. Invest. 14, 303 (1965).

[2] Caro, L. G.: High resolution Autoradiography II. The problem of resolution. J. CeLt Biol. 15, 189 (1962).

[3] -, P. v. Tubergen, and J. A. Kolb: High resolution autoradiography I. Methods. J. Cell Biol. 15, 173 (1962).

[4] Felomarn, Ch.: Range of $1-10 \mathrm{keV}$ electrons in solids. Phys. Rev. 117, 455 (1960).

[5] Granboulan, P.: Resolving power and sensitivity of a new emulsion in electron microscope autoradiography. J. Roy. micr. Soc. 81, 165 (1963).

[6] -, N. Granbodlan, and W. Bernhard: Application de l'autoradiographie a la microscopie electronique. J. Microscopie 1, 75 (1962).

[7] HaAse, G., u. G. JUNG: Herstellung von Einkornschichten aus photographischen Emulsionen. Naturwissenschaften 17, 404 (1964).

[8] LIqUIER-Mirward, J.: Electron microscopy and radioautography as coupled techniques in tracer experiments. Nature (Lond.) 177, 619 (1956).

[9] Nelms, A. T.: Energy loss and range of electrons and positrons. National Bureau of Standards Circular 577 and Suppl. (1956).

[10] PeLc, S. R.: Theory of electron autoradiography. J. roy. micr. Soc. 81, 131 (1963).

[11] -, J. D. CoomB ES, and C. C. BUdD: On the adaption of autoradiographic techniques for use with the electron microscope. Exp. Cell Res. 24, 192 (1961).

[12] SALPETER, M. M., and L. BaChMANN: Autoradiography with the electron microscope a procedure for improving resolution, sensitivity, and contrast. J. CELL Biol. 22, 469 (1964).

Quantitative Autoradiographie im Elektronenmikroskop. Vortrag auf der gemeinsamen Tagung der Deutschen Ges. f. Biophysik e. V., der Österr. Ges. f. reine u. angew. Biophysik und der Schweiz. Ges. f. Strahlenbiologie, Wien, 14. - 16. Sept. 1964.

[13] SilK, M. H., A. O. Hawtrey, J. M. Sperrce, and J. H. S. Gear: A method for intracellular autoradiography in the electron microscope. J. biophys. biochem. Cytol. 10, 577 (1961).

D. F. HüLSER and Dr. M. F. RAJEWSKY

Max-Planck-Institut für Biophysik

6 Frankfurt am Main S 70, Kennedyallee 70 